\title{
Somogy megye fülbemászói (Dermaptera)
}

\author{
SZIRÁKI GYÖRGY
}

SzIRÁKI GY.: Earwigs of Somogy county, Hungary (Dermaptera)

Abstract: Five earwig species found hitherto in Somogy county are listed. One of them may be regarded as remarkable insect from the nature conservation point of view.

\section{Bevezetés}

Magyarországon bizonyítottan csupán 6 fülbemászó faj él. Közülük 5 elókerült Somogy megyéból is. Gyújtések ennek az állatcsoportnak az esetében is fóként a Dráva mentén, valamint a Balaton-parton, illetve annak közelében történtek.

\section{A megyében megtalált fajok}

\section{Labiduridae}

Labidura riparia (Pallas, 1773) -

Kozmopolita faj. Magyarországon is gyakori. Elsősorban vizek mellett, laza talajon fordul elő.

\section{Labiidae}

Labia minor (Linnaeus, 1758) Kozmopolita faj. Magyarországon is meglehetősen gyakori. Elsősorban nedves élőhelyeken találhatjuk meg. Fényre jól repül.

\section{Forficulidae}

Anechura bipunctata (Fabricius, 1781) Mongóliától Dél-Európáig előforduló faj; nálunk ritka.

Apterygidia media (Hagenbach, 1822) Európa nagy részén előfordul. (Ukrajnától K-re nem.) Nálunk a keményfaligetek jellegzetes bőrszárnyúja.

Forficula auricularia Linnaeus, 1758 Kozmopolita faj; Magyarországon rendkívül gyakori.

\section{1. táblázat: Dematoptera fajok családonkénti megoszlása}

\begin{tabular}{|l|c|}
\hline Család & Fajszám \\
\hline Labiduridae & 1 \\
\hline Labiidae & 1 \\
\hline Forficulidae & 3 \\
\hline Összesen: & 5 \\
\hline
\end{tabular}




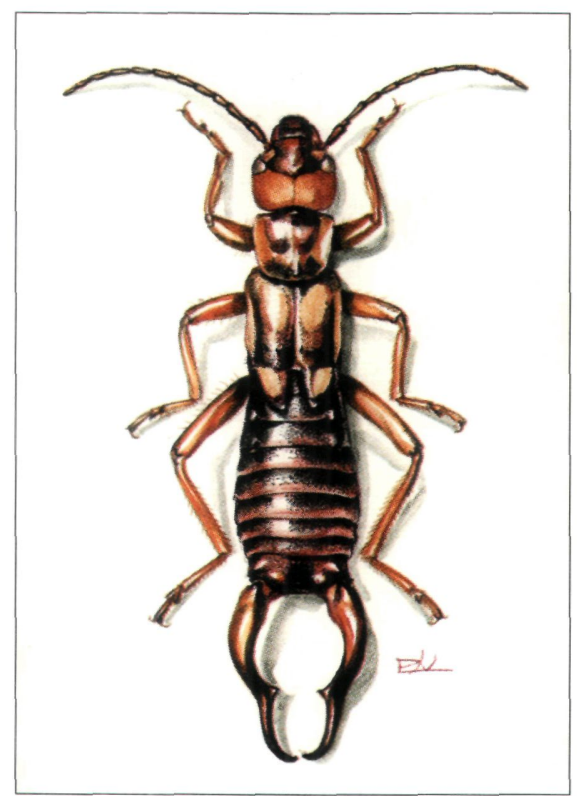

1. ábra: Kétpettyes fülbemászó (Anechura bipunctata)

\section{Természetvédelmi megítélés}

Természetvédelmi szempontból egy faj érdemel említést, nevezetesen a kétpettyes fülbemászó (Anechura bipunctata). E nálunk ritka, tólünk északra hiányzó bőrszárnyú bizarr alakú fogóival a többi hazai fajhoz képest feltúnó megjelenésú, és természeti értékként kezelendő. (A megyében Zamárdiból és Szántódról került eló.)

\section{Earwigs of Somogy county (Hungary) (Dermaptera)}

\section{GYÖRGY SZIRÁKI}

Hitherto five of the six Dermaptera species of Hungary are known from Somogy county. One of them (Anechura bipunctata) is worth mentioning from nature conservation point of view, as it is very rare in Hungary, and absent north of our country.

Author's address:

Dr. György SzIrÁkI

Hungarian Natural History Museum

H-1088 Budapest

Baross u. 13.

HUNGARY 